植込み型心臟ペースメーカの一部の機種において，X線CT検査中に当該製品が部分的電気的リセットを引き起こす不具合 事例については，本学会HP上で4月７日付け，5月9日付けでで案内したとおりです。

平成17年 5 月に厚労省医薬食品局より医薬品・医療機器等安全性情報 213 号が発出され，禁忌・禁止の項に「原則禁忌】当 該製品の植込み部位へのX線CT装置によるX線照射は行わないこと」となっております.

この医薬品・医療機器等安全性情報は, 厚生労働省において収集された副作用情報をもとに, 医薬品・医療機器等のより安 全な使用に役立てるために，医療関係者に対して情報提供されるものです，会員各位におかれましては，当該製品を植込まれ た患者が不用意にX線CT検査を受けることがないように適切な対応を講じるとともに，安全管理体制の徹底を図られるよう お願いいたします。

参考までに，厚生労働省医薬食品局からの医薬品・医療機器等安全性情報213号を掲載します.

医薬品・医療機器等安全性情報 (抜粋)

Pharmaceuticals and Medical Devices Safety Information No.213

平成17年 $(2005$ 年) 5 月 厚生労働省医薬食品局

\title{
1. X線CT装置が植込み型心臓ペースメーカ(メドトロニックInSync8040)へ及ぼす影響について
}

(1) 概要

メドトロニックInSync8040は，平成15年 5 月に，「使用目的」を「十分な薬物療法にもかかわらず改善の見られない，QRS幅 130ms以上及び左室駆出率 $35 \%$ 以下を伴う重症心不全に対する病状の改善」として承認された植込み型心臓ぺースメーカである.

販売開始の平成 16 年 4 月から平成 17 年 3 月末までの 1 年間で，当該製品の植込み患者において，X線CT検査中に当該製品 が部分的電気的リセット (以下「リセット」という)を引き起こした不具合事象が11件報告された.

検証の結果，これらはすべて臨床下におけるX線CT装置のX線が当該製品上を照射した際に引き起こされる事象であること が判明すると同時に，当該製品上をX線CT装置によるX線が照射中又は通過中にオーバーセンシングを引き起こしていること も判明した。

当該事象の発生については，当該製品の構造上の問題を否定できないこと, リセット発生時に早急な解除等の対応が実施さ れなかった場合に重篤な健康被害発生のおそれがあることから，速やかに措置を講じることとした．

(2)企業に対する指導内容

（1）メドトロニックInSync8040の添付文書について，次の事項について追記等の改訂を行い，併せて当該製品を扱う医療機 関の医師，診療放射線技師等の医療関係者に対し注意絪起を行うこととした。

ア)禁忌・禁止の項に「原則禁忌】当該製品の植込み部位へのX線CT装置によるX線照射は行わないこと。[リセットを引 き起こす可能性がある．]な抢，診療上やむを得ず照射を行う際には，当該製品の植込み施設又は患者フォローアッ プ施設に拀いて，脈拍をモニターすると共に，プログラマーによりリセットの解除等を速やかに行える専門医等の立 ち会いのもとX線照射を行うこと〔相互作用の項参照〕」と記載すること.

亿)また同様に, 使用上の注意の項の重要な基本的注意及び相互作用にX線CT装置を挙げ，相互作用の内容(臨床症状, 措置方法，機序，危険因子等)を簡潔に記載すること.

(2)すでに当該製品を埋込まれた患者が不用意に他の施設で診療上，X線照射を受けることのないよう患者手帳に追記する など適切な措置を講じることとした。

（3）また，X線照射によるリセットの原因を究明し，構造上の変更等を検討し，速やかに安全対策を講ずることとした．但 し，変更の内容が承認事項の一部変更の必要性を認める場合には，速やかに一部変更承認申請を行うこととした。 なお，同様他機種への影響を確認すべく関係企業に指示しているところである.

\section{（3）医療機関へのお願い}

(1)当該製品の植込み部位へのX線CT装置によるX線照射は行わないでください.

(2)診療上やむを得ずX線照射を行う際には, 当該製品の植込み施設又は患者フォローアップ施設において, 脈拍をモニ夕 一するとともに，プログラマーによりリセットの解除等を速やかに行える専門医等の立ち会いのもとX線照射を行うよ うにしてください。

（3）また，すでに当該製品を植込まれた患者が不用意に他の施設で診療上，照射を受けることのないよう，患者に対し，十 分な説明を行ってください。 